\title{
REFLECTIONS ON CHANGING LANDSCAPE OF PRIVATE HIGHER EDUCATION SPACE IN INDIAN HIGHER EDUCATION
}

\author{
Dr. K. M. JOSHI \\ Professor of Economics of Education \\ Maharaja Krishnakumarsinhji Bhavnagar University, Bhavnagar, India \\ Email: kmjoshi1972@gmail.com
}

Dr. Kinjal V. AHIR

Assistant Professor

Tolani Institute of Management Studies, Adipur, India

Email: kinjalahir@gmail.com

doi:10.13165/IE-14-8-2-01

\begin{abstract}
Higher education is now widely accepted as a foremost instrument for fostering economic growth. The Indian higher education system is the largest in the world in terms of the number of institutions and the second largest in enrollments. About 29.6 million students are currently enrolled in higher education institutions in India. There are around 712 universities and 36,671 colleges in India. This mammoth network of higher education institutions includes a large private sector that has emerged explicitly and outsized during last two decades. The overall share of the unaided private higher education institutions has reached 63.9 percent, and the share of student enrollments in these institutions has reached 58.9 percent. The authors make an attempt to present an overview of Indian higher education and within the same frame tries to delineate and identify the advent and growth of private higher education.
\end{abstract}

JEL classifications: I22, I23, I24, I28.

Keywords: Indian higher education, private higher education, regulation, access, financing, efficiency, quality, issues. 


\section{Introduction}

It is widely recognised that higher education promotes social and economic development by enhancing human and technical capabilities of society. Technical change and institutional change are key components of development. The Recent evidence substantiates and envisages that higher education is a determinant as well as the outcome of income, and can produce public and private benefits (Bloom, Hartley and Rosovsky, 2006).

During last six decades since independence, the Indian higher education has undergone a noteworthy transformation from an elite system to a mass system. The Indian higher education system is the largest in the world in terms of the number of institutions and the second largest in enrollments (Joshi and Ahir, 2015). About 29.6 million students are currently enrolled in higher education institutions in India. There are around 712 universities and 36,671 colleges in India (UGC, 2014 a). This mammoth network of higher education institutions includes a large private sector that has emerged explicitly and outsized during last two decades. The exponential growth of private higher education has been because of growth in the population in the relevant age cohort; lower cumulative drop-outs at earlier stages of education; increase the transition rate from secondary to higher education; increased demand for skilled workforce, greater purchasing power of the middle class; increasing fiscal pressures and prioritized ends in favor of other social sectors; conducive environment for private sector participation and increase in the private returns on higher education.

This paper makes an attempt to present an overview of India higher education and within the same frame tries to delineate and identify the space of private higher education in context of regulation, financing, equity, efficiency and quality.

\section{Regulatory structure of higher education in India}

Under the Constitution (42 ${ }^{\text {nd }}$ Amendment) Act of 1976, both the Central and the State governments are responsible for the promotion and development of higher education.

There are several statutory / regulatory bodies and about fifteen ministries / departments in the Government of India that establish, finance or regulate higher education institutions. Due to lack of a holistic policy or administrative approach their roles often overlap or even at times contradict each other. This scenario has thus resulted into a cobweb of judicial interventions often confusing more than clarifying the emerging ideological and operational contradictions.

The Central government is vested with the powers of coordination and determination of standards in institutions of higher education, technical education and research institutions. The Central government exercises its powers through the apex body of higher education - the Ministry of Human Resource Development (MHRD), Department of Higher Education by providing policy and leadership. In order to discharge its responsibilities, the Central government established the Universities Grants Commission (UGC) for the coordination, determination, and maintenance of standards of university education. The state governments 
have a significant role in funding of higher education and also have the major stake in all administrative and operational matters.

Universities, colleges, and stand-alone institutions deliver higher education in India. A University is empowered to award degrees under an Act of Parliament or State Legislature or Gazette Notifications. Colleges are affiliated / recognized by a university and not authorized to award their degrees. Even stand-alone institutes do not grant a degree, but they offer a diploma course.

In India, universities and colleges can be purely government/public or private with proprietorship and funding both in the hands of a private entity or private with proprietorship and funding from government or any form of public-private partnership mode.

In the context of universities, private universities and private deemed-to-be-universities are funded by private resources and have private proprietorship. Private colleges are of two types: 'Private- Aided' colleges (privately managed but publicly funded) and 'Private-Unaided' colleges (privately managed and funded). The private aided institutions charge very low fees of all types, whereas, the private unaided charge different types of fees which are high. With reduced funding in public institutions and to generate additional revenue, many public institutions (both universities and colleges) have started offering full-cost programs.

In India, few foreign educational institutions exist in a purely private mode or PrivatePrivate Partnership or Public Private Partnership (PPP) mode. The foreign education providers' bill has been awaiting parliamentary approval for the past three years but new rules, an executive order on "the Operation of Campuses of Foreign Education Institutions" will allow foreign universities to award foreign degrees under the University Grants Commission.

A major restructuring is envisioned to reform Indian higher education to enhance access, quality and make it globally competitive. Establishment of a national level apex body National Commission on Higher Education and Research (NCHER) to ensure autonomy of institutions and enhancement of standards as suggested by the Yashpal Committee Report (2008) and the NKC (2009) is under consideration. This regulatory body is expected to subsume all the other regulatory bodies to avoid the overlap of the functions and to resolve issues transparently arising out of varying and sometimes conflicting regulatory provisions mandated by regulatory bodies and professional councils.

\section{Growth of Indian Higher Education by Institutes and Enrollments}

The Indian higher education system is the world's largest higher education system in terms of number of institutions followed by China (Joshi and Ahir, 2015). Higher education in India has experienced a significant hike in the number of institutions since Independence. The universities / university level institutions registered a 23 fold increase (from 30 in 1950-51 to 712 in 2012-13) and colleges registered a 51 fold increase (from 695 in 1950-51 to 36,671 in 2012-13) (UGC, 2014 a). This hike has been more prominent in the post-2000 period. During the last 13 years, the quantum of both the universities and colleges increased by almost 2.75 times as shown in figure 10.1 . 
Both in retrospect and recent, the State governments have played a decisive role in the provision of higher education in India. Of the total universities in 2012-13, State Universities were about 43 percent, 20 percent were State Private Universities, 18 percent were Private Deemed Universities, about 10 percent were Institutions of National Importance and around 6 percent were Central Universities (UGC, 2014 a). Thus, private universities accounted for a significant share of 38 percent of the total universities. While the growth of the state and the central government university level institutions had almost stagnated, the private sector grew considerably and changed the landscape of Indian higher education (Joshi and Ahir, 2014).

Figure 10.1: Decadal growth of number of Universities and Colleges 1950-2013

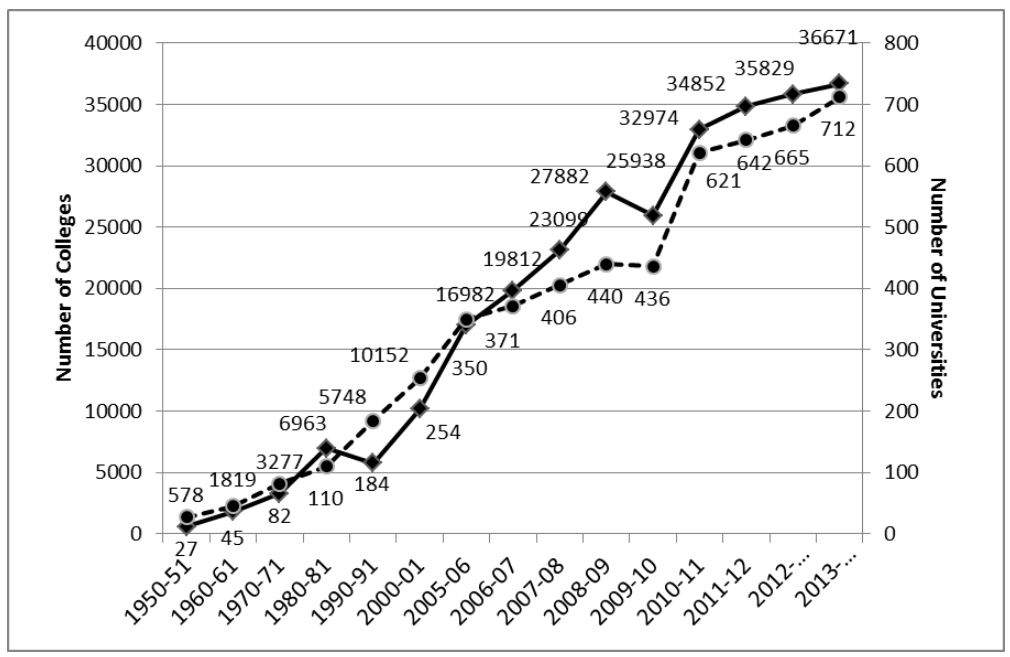

Source: UGC, 2014 a

A noteworthy achievement of the Indian higher education has been the rise in absolute enrollment that made it the world's second largest higher education system by enrollment. At the time of independence in 1947, the enrollment in higher education was 0.21 million. From 1950-51 to 2000-01, i.e. over six decades the enrollments increased from 0.39 million to 8.4 million. However, during 2000-01 to 2012-13, i.e. in about one decade with the prolific growth of private institutions, the enrollments registered a three-fold growth and reached 29.6 million as shown in figure 10.2. Of the total enrollments in 2012-13, 8 percent students were enrolled in stand-alone institutions, 23 percent were enrolled in universities and 69 percent students were enrolled in colleges (MHRD, 2014 a). Thus, colleges enrolled almost 70 percent of all of India's higher education students. 
Figure 10.2: Decadal growth of student enrollments in higher education since 1950-2013

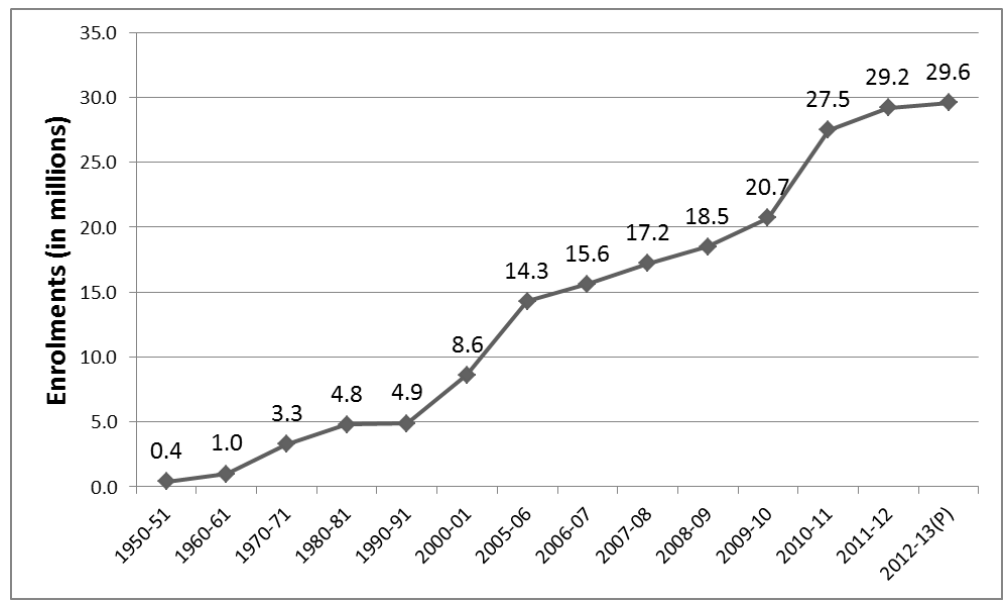

Source: UGC, 2014 a

Of the total number of colleges about 30 percent colleges enrolled less than 100 students and another 36 percent enrolled between 100 to 500 students. Around 4 percent of the colleges enrolled more than 3000 students (MHRD, 2014 b).

Across India, the undergraduate level enrollments were the highest amounting to almost 79 percent of the total students. About 12 percent pursued the postgraduate program, and about 8 percent students enrolled at diploma level. However, the other levels of higher education like the Ph.D., M.Phil., Postgraduate diploma, certificate and integrated courses registered about 2 percent of the total students (MHRD, 2014 a). Across the nation, affiliated colleges enrolled 90 percent of the graduates, 70 percent of the postgraduates and 17 percent of doctoral students (Planning Commission, 2013).

In India, during 2011-12 of the total universities, 55 percent universities offered multidisciplinary education while among the specialist universities there were 14 percent technical universities, 6 percent agricultural universities and 5 percent medical universities. During the same period, about 67 percent colleges offered general courses. Amongst the colleges that offered specific discipline fields, about 7 percent offered engineering and technology, 6 percent offered education / teacher education, about 3 percent nursing, about 2 percent management and Pharmacy each. In 2011-12, almost 42 percent colleges offered single programs of which about 35 percent colleges offered Bachelor of Education course only (MHRD, 2014 b). The private sector dominated in these professional programs. Such isolated islands of higher learning compartmentalize and leave lesser scope for interdisciplinary, holistic approach (Yashpal, 2008). 
Higher education enrollments in India have been dominated by four faculties, viz., Arts, Science, Commerce/Management and Engineering and Technology (MHRD, 2013 a \& b, 2014 b). It shows that the share of arts (including social sciences), engineering/technology, commerce, and science have been 39.69 percent, 16.6 percent, 14.74 percent and 12.21 percent respectively in 2011-12. Conventional subjects like arts, science and commerce reflects a larger concentration of students and accounts for almost 60 percent of the undergraduate students. Over the years, the preference for general subjects has been declining, but they still dominate. About 21 percent of the students had chosen technical subjects like engineering/technology, IT, and computer sciences. The share of technical subjects has witnessed a rise over the years with a decline in the enrollment share of general subjects.

However, it is noteworthy that over the five decades from 1950-51 to 2000-01 the GER registered a growth from 0.4 percent to 8.1 percent. However, in just about a decade during 2001-13 the GER registered an upsurge from 8.1 percent to 21.1 percent as shown in figure 10.3. Despite massive enrollment in Indian higher education, the GER of 20.4 percent is still very low when compared to other countries. With about 80 percent of the age cohort persons still outside the ambit of higher education, effective policy initiatives to confront the challenges associated with providing an equitable access is imperative (MHRD 2013 a; UGC, 2013).

Figure 10.3: Gross Enrolment Ratio for Indian higher education

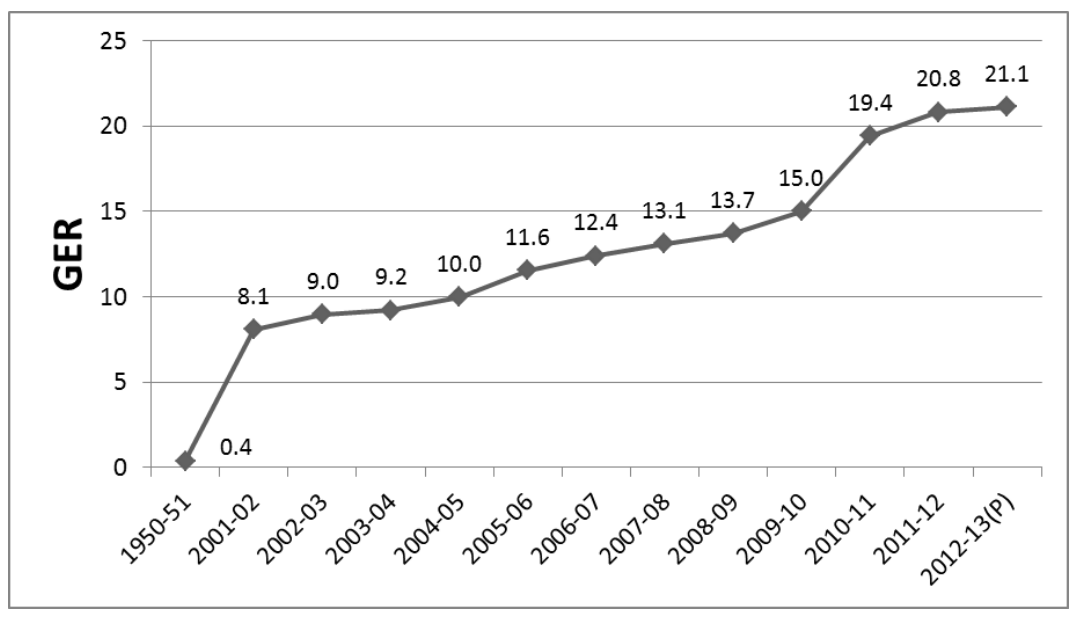

Source: UGC, 2014 a 


\section{Financing of Higher Education in India}

The financing of higher education in India is a collective responsibility of the center and the state. Private financing has come to acclaim the larger share in the growth of higher education.

In absolute terms, at nominal prices, the share of the government expenditure on higher education increased remarkably from Rs. 23.12 billion (State's share - 18.36 billion, Center's share - 4.76 billion) in 1990-91, to 91.95 billion in 2000-01 (State's share - 69.1 billion, Center's share - 22.85 billion). In 2009-10, the share of government expenditure on higher education amounted to Rs. 466.33 billion (State's share - 280.15 billion and Center's share 186.18 billion). Thus at nominal prices there has been about 20 fold increase over two decades from 1990 to 2010. But in relative terms, the inflationary price rise rendered this massive growth insufficient, as at relative prices the government expenditure on higher education has actually registered a decline (CABE, 2005; MHRD, 2013 c). With the increase in the absolute government expenditure, the share of government expenditure on education as percentage of GDP increased gradually from 2006-07 to 2010-11 from about 3.64 to about 4.17 but that on higher education (inclusive of technical education) increased at a lesser pace from about 1.14 to 1.34 respectively. The contribution of the government expenditure on higher education alone remained almost stagnant at 0.7 in 2006-07 and 0.76 in 2011-12.

The low resource allocation has impeded the development of institutional infrastructure with severe implications on quality.

Historically, the state governments have played a greater role in financing government expenditure on higher education. Since 1990s, the state governments contributed almost 80 percent in financing higher education in India. However, from early 2000s, the share of the state governments declined to 70 percent and in 2011-12 to about 60 percent. While the central government's budgetary allocations have increased over the period, it appears skewed in favor of few higher education institutes comprising of a very small number.

The biggest share of state funding, about 85 percent is spent on administrative expenditure with only 15 percent being spent on capacity building (FICCI, 2011). Most of the state funds are diverted towards maintenance of the infrastructure and remuneration to the faculties, sparing lesser funds for establishing new infrastructure and capacity building.

The fee levels in the state universities have been very low and not substantial to cover the operating costs. Scholarships covered only 2 percent of the student population and education loan schemes covered only 1 percent of the students (due to very high-interest rates) (FICCI, 2009).

Various other modes of revenue generation for higher education institutions also lack any regulatory motivation like the tax rebates. Thus, both public and private higher education institutions have not been able to mobilize enough resources in the form of corporate sponsorships, philanthropic contributions, donations for infrastructural development, etc. Various other avenues of revenue generation like philanthropic contributions, resource generation by the asset utilization, university-industry linkage, etc, have been largely untapped 
by the majority of both public and private institutions. In the absence of an alternative and additional revenue sources, the private institutes are likely to shift the burden to the students or their families (Joshi and Ahir, 2007).

\section{Equity Issues in Higher Education in India}

Indian society is characterized by a high degree of structural inequalities, based on the institutions of caste and ethnicity (Thorat \& Mahamallik, 2005). The access to higher education in India reflects discrepancy across various categories of the population. In India six categories of diversities exists: ethnic-based diversity (Scheduled Castes - SC, Scheduled Tribes - ST, and Other Backward Classes - OBC), religion based diversity (between Muslims and NonMuslims) financial need based diversity (between poor and non-poor), gender-based diversity (between male and female), regional diversity (between rural and urban area), and inter-state disparities (Joshi \& Ahir, 2014). By religious classification, in 2009-10, the Muslim people were found to have the lowest GER (11) while Zoroastrian people were found to have the highest GER (64). The GER for Buddhist, Hindu, Sikh and Christian were about 18, 20, 23, and 31 respectively.

The GER for males was 22.3 while that for females it was 19.8 in 2012-13 (UGC, 2014 a). On the basis of ethnic backgrounds too, enormous disparities in GER can be observed. The GER for the non-disadvantaged group was 21.1 in 2012-13. However, the GER of the most impoverished group ST was 11, whereas the GER for the other disadvantaged groups SC was 15.1 (UGC, 2014 a). The GER for OBC was 18 in 2011-12. The GER for rural areas was observed to be far lower (about 14) than that of urban areas (about 33) (Joshi and Ahir, 2014). The discrepancies across various segments of the population impede the efforts to increase the overall GER of the country. The overall average of the country's GER cannot be raised without raising the GER of the impoverished and disadvantaged sections of the society.

The most prominent policy for promoting access to higher education has been reservations. The policy of reservation in higher education is based on the assertion that the participation of disadvantaged groups has been low, and reservation would enhance their participation. Along with reservation, the government provision of scholarships, special hostels, meals, book loans and other schemes exclusively for ethnic-based students have encouraged the participation (Joshi, 2010).

Although all these policies have partially benefitted the students from the particular groups, an extensive section of economically weak but socially non-disadvantaged groups remains out of the ambit of effective access. The private sector has played a vital role in enhancing overall access but for the disadvantaged and impoverished group, the role of government and private aided colleges remains incomparable to others. 


\section{Status of Quality and Efficiency in Higher Education in India}

An increasing number of institutions and enrollments can be a necessary condition for development but not a sufficient condition. The issues related to quality and efficiency of higher education become more significant while considering the opportunity cost of attending the tertiary education in developing countries. In India, most of the Indian higher education institutes are under the domain of National Assessment and Accreditation Council (NAAC) established in 1994 for quality assurance. The other authorities responsible for maintenance of standard and its evaluation are National Board of Accreditation (NBA), National Council for Agricultural Research (NCAR) and various councils of the regulatory bodies established for institutes offering courses in nursing, medical, distance learning, etc. These all authorities (excluding NAAC) cover less than 10 percent of the total institutions of higher education in India. NAAC undertakes institutional accreditation (as against NBA that undertakes program accreditation) and accredits institutes on seven criteria bifurcated into 32 key aspects with weighted average assigned to each aspect. Criteria are differently weighted for universities, autonomous colleges, and affiliated colleges with respect to the differences in the role that they are expected to perform. The accreditation is valid for five years after which the institutes have to opt for reaccreditation. The accreditation was voluntary in past but as per the Gazette notification of January 2013, it is mandatory now for institutes to get accredited and assessed, failing which the NAAC can also influence funding (for aided institutes) or notification validity (for unaided institutes). Till 2014, 659 universities had accredited themselves, out of which 85 universities' accreditation was invalidated because either their accreditation period had expired or the letter of intent for next cycle of accreditation was pending for acceptance. Thus, 574 universities had valid accreditation (NAAC, 2014).

Similarly, until the beginning of 2014, 2910 colleges had valid accreditation across the states. By March 2010, only 38.4 percent of the universities that were accredited scored A grade, 57.9 percent $B$ grade and 3.8 percentage scored $C$ grade. In case of colleges, only 10.1 percent could score grade A, 68 percent scored B, and the other 21.9 percent scored $\mathrm{C}$ grade (Joshi and Ahir, 2014). The low grading to the institutions has been a consequence of vacant faculty positions, appointment of unqualified and ad hoc faculty, poor student-teacher ratio, poor infrastructure especially in case of library facilities, etc. Amongst the accredited and assessed colleges and universities, a major share is of government and private aided institutions. A majority of private universities and unaided colleges are still unaccredited and non-assessed. Therefore, with the growth of private sector, it becomes more imperative to keep all the stakeholders well informed about their large investment, for which the information about the outcome of institutional accreditation and assessment shall be vital. Although accreditation and assessment have been made mandatory, doubts are being raised regarding the ability of NAAC to accomplish a massive task of accrediting a huge number of institutions. Besides this, program assessment is still an unfinished agenda, which is more germane than institutional accreditation. Poor quality plagues the mass Indian higher education. Even the best performing institutes (which are public institutions) have failed to achieve decent ranks in any of the top three global 
higher education institute rankings, namely 'The Times Higher Education World University Rankings', Shanghai Jiao Tong University's 'Academic Rankings of World Universities' and the 'Quacquarelli Symonds (QS) System' rankings (Joshi and Ahir, 2014).

Although the scientific publications and the citation impact of papers emanating from India has increased and the growth in absolute number is appreciable, but while comparing with other emerging economies and given the size of Indian higher education, the relative number reflects the need for improvement (Joshi and Ahir, 2014).

In the context of efficiency, the private rates of returns for higher education do not support the Psacharopolous hypothesis of diminishing returns to education. Duraisamy (2000) found private rates of returns on higher education at 11.7 percent and Agrawal (2011) at 15.9 percent, highest across all levels of education. Thus, the private rates of returns are substantial at the level of higher education too, which encourages individuals to pursue further education.

Despite the high private rate of returns, the unemployment rates are highest at higher levels of education measured at 9.4 for graduates and 10 for postgraduates (MOLE, 2012).

\section{Private Higher Education in India: History, Empirical Mapping and Growth}

After independence, the ideological orientation emphasized in a state-dominated model that resulted in 'nationalization' / 'publicisation' of private higher education. The drawbacks of public higher education were apparent, and a say of opposition began at the beginning of 2000 . In 2000s consistent attempts were made to authorize private sector to establish higher education institutions with degree-granting powers to move away from stringent and restrictive regulatory clutches. The contribution of the private sector in enhancing the capacity creation in the Indian higher education has been colossal. By institutional framework, the presence of private sector in the Indian higher education encompasses of state private universities, private deemed universities, private 'aided' and private 'unaided' colleges and the 'self-finance' courses run by government universities and colleges. The contribution of the private sector has increased significantly during last one decade, as observed from the growth in the number of institutions. In 2001, the share of private unaided institutes in total higher education was 42.6 percent, and it enrolled 32.8 percent of the total students. By 2006, the share of private institutes increased to 63.2 percent and the student enrollment share increased to 51.5 percent (Sudarshan and Subramanian, 2012). In 2012, the overall share of the unaided private higher education institutions reached 63.9 percent, and the share of student enrollments in these institutions reached 58.9 percent (FICCI, 2013). Private universities growth has marked a phenomenal rise in the last decade. In 2004, there were 14 state private universities, which reached 154 in 2013, and it further rose to 174 in 2014 (FICCI, 2013, UGC, 2013, 2014 b). Within a decade, the state private universities grew more than 12 times. Most of them grew with the financial assistance from the corporate sector (FICCI, 2013). In the context of total deemed universities; about 70 percent of them are private deemed-to-be-universities (UGC, 2013). To cope up with the resource crunch and to generate additional revenue, government institutions too started offering self-finance courses. In 2011-12, stand-alone institutions were mainly run by the private sector 
with 78.7 percent institutions managed by the private sector, and only 21.3 percent institutions were in the government sector. About 58 percent of the colleges (private unaided) in the private sector did not receive government funding and were sponsored and managed by private funding. The private aided colleges that were 15 percent of total colleges received government funding (MHRD, 2013 a). The government funds the recurrent expenditure and in several cases even capital expenditure. Therefore, it is a misnomer to address them as 'private'. The diploma awarding stand-alone institutions structure has largely flourished in the private sector across all the disciplines. 75.7 percent of all the stand-alone institutions operate in the private sector while only 24.3 percent institutions are in the government sector. The private sector institutions also consists of about 70 percent of the stand-alone institutions offering technical education in the polytechnics, almost 80 percent of the institutes offering teacher training, about 85 percent of the institutes providing nursing education and more than 90 percent of the institutes offering Postgraduate diploma in management (MHRD, 2013 a). Private sector participation is more prominent in professional courses.

In 2011-12, private institutes accounted for 58.9 percent of the total enrollments followed by state public institutions (38.5 percent) and central public institutions (2.6 percent) (Planning Commission, 2013). Colleges enroll maximum number of students in the higher education system. The share of government colleges in the institutional count was 27 percent while the enrollments in it were 38 percent in 2011-12. The share of private aided colleges was 15 percent while its contribution in the enrollment was 24 percent. As against these two types of colleges, the share of the private unaided colleges in total colleges was 58 percent, but the enrollments in unaided colleges were 38 percent.

The private sector is mainly funded from the fees charged to the students. About 60 percent students enrolled in private unaided institutions pay full fees; the remaining 40 percent enrolled in public-funded institutions pay very low fees. The contribution of households to the revenue stream of higher education institutions in India was around 50 percent in 2005 (Agarwal, 2006), which has increased in recent time with inflation.

Though by law a private institute of higher education cannot operate in a 'for-profit' mode as per the respective trust registration, but they are earning profits that are not largely reinvested in higher education (Varghese, 2012; Agarwal, 2006). Students are charged fees with a variety of heads like, tuition fee, examination fee, entrance fee, admission fee, sports fee, library fee, laboratory fee, convocation fee, etc. Many private institutions charge extortionate and different fees, beyond approved and prescribed rules to the magnitude of non-affordability for the most of the students (Yashpal, 2008).

While there is almost a consensus regarding the participation of private higher education, but the debates surrounding funding patterns and regulatory oversight still lack transparency. It results in indistinctness in norms and policies for the private sector participation (UGC, 2011). Private higher education in India is both over regulated and unregulated. Many judicial interventions have provided directions to clarify the ideological or regulatory role of the higher education institutions concerning the overlapping role and functions of regulatory 
bodies. In many circumstances, the judicial interventions render the future of institutions, and students enrolled, by creating more confusion amongst the stakeholders.

\section{Conclusion}

Indian higher education has a long history of private institutions but in a scattered manner, subsequently getting attached to the state. The 'non-state funding resources' have been important in the growth of Indian higher education in its initial stages of development. The demand for higher education has increased substantially with improvement in the school education and anticipated labour market opportunities. The private sector participation has grown considerably. An insight into the negative features of private higher education system throws light on quality disparity, inequality, under qualified faculties, lack of research, etc. However, this system has its own very strong successes. The private education institutions have been able to fulfill the private demand for higher education, in the absence of the capacity of the state to do so. It is these institutions that have made higher education more accessible. The existence of high number of private institutions and high enrollment in the private sector has been able to save the public resources significantly. The professional orientation based programs have been more effective than the general courses. It is these private institutions that have proved to be successful in providing education in accordance with the labour market. Another positive aspect of selected private institutions is their true contribution to generate equity through their extensive financial support for the poor students, although they are very few in numbers. The government is not in a position to even sustain the present system, although expansion remains a dream. Because of growing private demand and in the absence of sufficient resources, the role of private sector has to be recognized by the government in its policy while including the profit as an objective of their entrance and existence.

India has the largest target market for higher education in the world, with a population of 234 million in the age group of 15-24 years. The FICCI report (2011) also observes that only India is the fastest growing market for higher education market as the youth population in the age group $18-24$ years is expected to increase to about $13 \%$ by 2020 . However, for the same period it is expected to be $12 \%$ for China and the world average is expected to be $4 \%$. If India is to meet its $30 \%$ GER target by 2020 , about 40 million students would be enrolled in the higher education system in 2020 and for this a large share of funding will have to come from private sector. India needs to train 500 million skilled laborers by 2022 to meet its requirement and also for attaining the status of world-wide sourcing hub. The government of India has recognized this and mobilized private industries to address the issue as this is likely to provide the profitable business opportunity of more than $\$ 20$ billion. The private sector participation in higher education through partnerships is being encouraged to address the anticipated demand. The private higher education during almost last one decade in India has taken place on a larger scale and will further accentuate in the coming years. The government has proposed different models of Public-Private Partnerships in higher education and acknowledged the need for change. 
Rather than opposing, the vicinity of time and circumstance has come near to recognize the significance of the private sector and facilitate its functioning. It is also necessary to provide level playing field to the private players through subsidies for research and excellence. The policy makers and practitioners must make efforts to encourage private sector to enhance their qualitative teaching and research output along with their input for equity.

\section{References:}

1. Agarwal, P. (2006). Higher Education in India: The need for change. ICRIER Working Paper, Indian Council for Research on International Economic Relations: No. 180.

2. Agrawal, T. (2011). Returns to Education in India: Some Recent Evidence, Indira Gandhi Institute of Development Research, Retrieved as on 15 th December, 2012 from http://www.igidr.ac.in/pdf/publication/WP-2011-017.pdf

3. Bloom, D. E., Hartley, M. \& Rosovsky, H. (2006). Beyond Private Gain: The Public Benefits of Higher Education. In P. G. Altbach \& J. Forrest (Eds.), International Handbook of Higher Education. Springer, Dordrecht, Netherlands. pp: 293-308.

4. CABE (2005). Report of the CABE Committee on financing of higher and technical education. Central Advisory Board of Education, National Institute of Educational Planning and Administration, New Delhi, June.

5. Duraisamy, P. (2000). Changes in Returns to Education in India, 1983-94: By Gender, Age-Cohort and Location. Economics of Education Review, 21:6. pp: 609-622.

6. FICCI (2009). Making the Indian Higher Education System Future Ready. FICCI Higher Education Summit 2009, Ernst \& Young Pvt. Ltd. Retrieved as on $1^{\text {st }}$ February, 2014 from http://www.edgex.in/resources/FICCI_EYReport2009.pdf

7. FICCI (2011). Private sector participation in Indian higher education. FICCI Higher Education Summit 2011, Ernst \& Young Pvt. Ltd. Retrieved as on $1^{\text {st }}$ February, 2014 from

http://www.ey.com/Publication/vwLUAssets/Private_sector_participation_in_Indian_hi gher_education/\$FILE/Private_sector_participation_in_Indian_higher_education.pdf

8. FICCI (2012). Higher education in India: $12^{\text {th }}$ five year plan (2012-17) and beyond. FICCI Higher Education Summit 2012, Ernst \& Young Pvt. Ltd \& Planning Commission.

Retrieved as on $1^{\text {st }} \quad$ February, 2014 from http://www.ey.com/Publication/vwLUAssets/Higher_Education_in_India/\$File/EYFICC_Higher_Education_Report_Nov12.pdf

9. FICCI (2013). Higher Education in India: Vision 2030. FICCI Higher Education Summit 2013, Ernst \& Young Pvt. Ltd. Retrieved as on $1^{\text {st }}$ February, 2014 from http://www.ey.com/Publication/vwLUAssets/Higher-education-in-India-Vision2030/\$FILE/EY-Higher-education-in-India-Vision-2030.pdf

10. Joshi, K. M. (2010). Higher Education and the Largest Impoverished and Marginalized Group of the Indian Population: Reviewing Enrolment and Access to Higher Education among Tribals in India. Asian Social Work and Policy Review, 4(2). pp: 57-65. 
11. Joshi, K. M., \& Ahir, K. V. (2007). Economics of Privatization: An introspection of Indian higher education. Indian Development Review: An International Journal of Development Economics. Serials Publication, Volume 5 No. 2.December. pp: 317-340.

12. Joshi, K. M., \& Ahir, K. V. (2014). Higher Education in India: Reflections on Changing Landscapes. In K. M. Joshi \& S. Paivandi (Eds.) Higher Education Across Nations, Volume II, B. R. Publishing Corporation, Delhi. ISBN- 9789350501368

13. Joshi, K. M. \& Ahir K. V. (2015). The state of Higher education governance in India: A perspective. In K.M. Joshi and Saeed Paivandi (Eds.) Higher Education Governance Across Nations. B.R. Publishing Corporation, Delhi. (In press)

14. MHRD (2013 a). All India Survey on Higher Education 2011-12 (Provisional). Department of Higher Education, Ministry of Human Resource Development, Government of India, New Delhi. Retrieved as on $22^{\text {nd }}$ January, 2014 from http://mhrd.gov.in/sites/upload_files/mhrd/files/AISHE2011-12P_1.pdf

15. MHRD (2013 b). All India Survey on Higher Education 2010-11. Department of Higher Education, Ministry of Human Resource Development, Government of India, New Delhi. $\begin{array}{llllll}\text { Retrieved as } & \text { on } & \text { and } & \text { January, } & 2014 & \text { from }\end{array}$ http://mhrd.gov.in/sites/upload_files/mhrd/files/AISHE201011.pdf

16. MHRD (2013 c). Analysis of Budgeted Expenditure on Education 2009-10 to 2011-12. Planning and Monitoring Unit, Department of Higher Education, Ministry of Human Resource Development, Government of India, New Delhi.

17. MHRD (2014 a) All India Survey on Higher Education 2011-12 (Final). Department of Higher Education, Ministry of Human Resource Development, Government of India, New Delhi. Retrieved as on $22^{\text {nd }}$ January, 2014 from

18. http://mhrd.gov.in/sites/upload_files/mhrd/files/statistics/RptAISHE2011-12_0.pdf

19. MHRD (2014 b) All India Survey on Higher Education 2012-13 (Provisional). Department of Higher Education, Ministry of Human Resource Development, Government of India, New Delhi. Retrieved as on $22^{\text {nd }}$ January, 2014 from http://mhrd.gov.in/sites/upload_files/mhrd/files/statistics/AISHE2012-13_0.pdf

20. MOLE (2012). Report on Employment and Unemployment Survey: 2011-12. Ministry of Labour \& Employment, Government of India, New Delhi.

21. NAAC (2014). Universities - Accreditation Status (as on 21.2.14). National Assessment and Accreditation Council, An autonomous institution of the University Grants Commission, Bangalore. Retrieved as on 23.3.14 from http://www.naac.gov.in/docs/Statuspercentage20-ercentage20Universitiespercentage205percentage203percentage2014.pdf

22. NKC (2009). Report to the nation: 2006-2009. National Knowledge Commission, Government of India, March.

23. Planning Commission (2013). Twelfth Five Year Plan (2012-17), Social Sectors, Volume III. Government of India, Sage Publications India Private Limited, New Delhi.

24. Sudarshan, A. \& Subramanian, S. (2012). Private Sector's Role in Indian Higher Education, India Infrastructure Report 2012- Private Sector in Education, Infrastructure 
Development Finance Company Limited. pp: 178-184, Retrieved as on 2.4.14 from http://www.idfc.com/pdf/report/2012/Chapter_16.pdf

25. Thorat, S., \& Mahamallik, M. (2005). Persistent Poverty - Why do Scheduled Castes and Scheduled Tribes Stay Chronically Poor, Paper presented at the 2005 PRCIIPA SEMINAR, PRCIIPA, New Delhi. September 29-30.

26. UGC (2011). Inclusive and Qualitative Expansion of Higher Education, $12^{\text {th }}$ Five Year Plan, 2012-17. University Grants Commission, New Delhi. November.

27. UGC (2013). Higher Education in India at a Glance 2013, University Grants Commission, New Delhi. June. Retrieved as on $20^{\text {th }}$ January, 2014 from http://mhrd.gov.in/statistics_data?tid_2=239

28. UGC (2014 a). Education in India at a Glance 2014, University Grants Commission, New Delhi. June. Retrieved as on $20^{\text {th }}$ January, 2014 from http://mhrd.gov.in/sites/upload_files/mhrd/files/statistics/EAG2014.pdf

29. UGC (2014 b). List of Private universities in India as on March 2014. Retrieved as on 28th March, 2014 from http://www.ugc.ac.in/privatuniversity.aspx

30. Varghese, N. K. (2012). Private Higher Education: The Global Surge and Indian Concerns. India Infrastructure Report 2012-Private Sector in Education, Infrastructure Development Finance Company Limited. pp: 145-156. Retrieved as on $2^{\text {nd }}$ March 2014 from http://www.idfc.com/pdf/report/2012/Chapter_13.pdf

31. Yashpal (2008). Report of the Committee to Advise on Renovation and Rejuvenation in Higher Education. Yashpal Committee Report. Ministry of Human Resource Development, Department of Higher Education, Government of India, New Delhi. October 14 .

\section{About the Authors:}

Kishore MAHENDRAJOSHI, PhD., Prof, Department of Economics, Maharaja Krishnakumarsinhji Bhavnagar University, India.

Research fields: Economics of Higher Education, Higher Education Governance, Sociology of Education and Private Higher Education.

Kinjal VIJAYAHIR, PhD., Faculty of Economics, Tolani Institute of Management Studies, India.

Research fields: Economics of Higher Education, Private Higher Education, Quality \& Equity Issues in Higher Education. 